\title{
MEWUJUDKAN PUTUSAN HAKIM YANG BERKEADILAN MELALUI HERMENEUTIKA
}

\author{
Suparnyo \\ Universitas Muria Kudus \\ Kampus UMK Gondangmanis Bae Kudus, Kudus \\ E-mail: suparnyo@umk.ac.id
}

\begin{abstract}
This article aims to describe how the legal decision-making process through hermeneutics should be. The aim is to obtain a legal ruling through a hermeneutic technique which is fair to all parties not only from the normative side but also on the substantive side. The method used is normative legal research conducted by reviewing and analyzing library materials in the form of legislation, documents and books relating to the issues to be discussed, namely how to compile a just legal decision through hermeneutics. In conclusion, a judge's decision will have authority if it is done through a method of interpreting the law that is clear and can be accepted by a wide audience.
\end{abstract}

Keywords: ruling, hermeneutics, justice.

\begin{abstract}
Abstrak
Artikel ini bertujuan untuk menguraikan bagaimana seharusnya proses pengambilan keputusan hukum melalui hermeneutika. Tujuannya adalah mendapatkan sebuah putusan hukum melalui teknik hermeneutika yang berkeadilan bagi semua pihak tidak hanya dari sisi normatif tetapi juga berdasarkan sisi substantif. Metode yang digunakan adalah penelitian hukum normatif yang dilakukan dengan cara mengkaji dan menganalisis bahan-bahan pustaka yang berupa perundang-undangan, dokumen dan buku-buku yang berkaitan dengan permasalahan yang akan dibahas, yaitu bagaiman amenyusun sebuah putusan hukum yang berkeadilan dengan melalui hermeneutika. Kesimpulannya sebuah putusan hakim akan memiliki wibawa jika dilakukan melalui metode penafsiran hukum yang gamblang dan dapat diterima oleh khalayak luas.
\end{abstract}

Kata kunci: putusan hukum, hermeneutika, berkeadilan. 


\section{PENDAHULUAN}

Hukum selalu berkaitan/berhubungan dengan kehidupan manusia, sehingga apabila kita membicarakan hukum maka juga tak dapat lepas dari membicarakan kehidupan manusia. ${ }^{1}$

Dalam kehidupannya manusia selalu mempunyai kepentingan, yang bahkan sudah mulai ada sejak manusia itu lahir di dunia. Kepentingan manusia yang satu dengan yang lain dalam kehidupan bersama/bermasyarakat dapat selaras, berbeda dan bahkan dapat juga bertentangan. Agar kepentingan yang bertentangan itu tidak menjadi konflik yang berkepanjangan, maka diperlukan pedoman atau peraturan hidup. Pedoman atau peraturan hidup tersebut menentukan bagaimana manusia harus bertingkah laku dalam masyarakat agar tidak merugikan orang lain atau dirinya. Pedoman tingkah laku dalam kehidupan bersama/masyarakat itulah yang disebut dengan kaidah/norma atau hukum. Kaidah, norma atau hukum diharapkan dapat berfungsi untuk mengurangi bahkan menghilangkan konflik tersebut, sehingga tercipta ketertiban dalam masyarakat.

$$
\text { Konflik di antara anggota }
$$
masyarakat dapat diselesaikan melalui

1 Sudikno Mertokusumo, 1988, Mengenal Hukum ( Suatu Pengantar ), Liberty, Yogyakarta, hal. 1. pengadilan dan juga dapat diselesaikan di luar pengadilan, seperti melalui Arbiutrase atau juga Alternatief Dispute Resolution. Apabila penyelesaian konflik dilakukan di pengadilan, maka hakimlah yang mempunyai tugas dan kewenangan untuk menyelesaikannya. Hakim di dalam menjalankan tugas dan wewenangnya yaitu untuk menegakkan hukum dan keadilan, harus mendasarkan pada Pancasila dan mencari dasar hukum serta asas-asas yang menjadi landasannya. ${ }^{2}$ Pendapat Radbruch sebagaimana dikutip Satjipto Rahardjo ${ }^{3}$ menyatakan bahwa nilai-nilai dasar dari hukum yang harus ditegakkan yaitu : kepastian hukum (rechts-sicherheit), kemanfaatan/kegunaan (zweckmassigkeit) dan keadilan (gerechtigkeit). Ketiga nilai dasar tersebut terdapat suatu spannungsverhaltnis, suatu ketegangan satu sama lain.

Permasalahan yang muncul dalam praktik peradilan adalah bagaimana apabila hakim menghadapi perkara/kasus yang tidak dapat ditemukan dasar hukumnya? Bagaimana mewujudkan putusan hakim yang berkeadilan sebagaimana yang diharapkan masyarakat, sehingga putusan tersebut berwibawa?

2 Sudikno Mertokusumo, 1982, Hukum Acara Perdata Indonesia, Liberty, Yogyakarta, hal. 18.

${ }^{3}$ Satjipto rahardjo, 1996, Ilmu Hukum, Citra Aditya Bakti, Bandung, hal. 19. 


\section{RUMUSAN MASALAH}

Berdasarkan uraian sebelumnya tulisan ini fokus pada bagaimana penerapan hermeneutika dalam menghasilkan putusan-putusan hukum yang berkeadilan?

\section{TUJUAN PENELITIAN}

Adapun tujuan dari tulisan ini adalah mendeskripsikan bagaimana prinsip-prinsp penerapan hermeneutika dalam menyusun sebuah putusan hukum yang berkeadilan. Karena dalam beberapa perkara, putusan yang diambil harus mengedepankan aspek kebenaran subtantif dibanding kebenaran normatif yang selama ini banyak dilakukan dalam sistem peradilan di Indonesia.

\section{METODE PENELITIAN}

Jenis penelitian yang digunakan adalah jenis penelitian hukum normatif, yaitu penelitian yang dilakukan dengan cara mengkaji norma atau kaidah yang berlaku dalam masyarakat, dan menjadi acuan perilaku setiap orang. Penelitian hukum normatif disebut juga penelitian hukum teoritis/dogmatik. Penelitian hukum normatif hanya menelaah data sekunder. Fokus kajian hukum normatif adalah inventarisasi hukum positif, asas-asas dan doktrin hukum, penemuan hukum dalam perkara in concreto, sistematik hukum, taraf sinkronisasi hukum, perbandingan hukum, dan sejarah hukum.

Penelitian ini dilakukan dengan cara mengkaji dan menganalisis bahan-bahan pustaka yang berupa perundang-undangan, dokumen dan buku-buku yang berkaitan dengan permasalahan yang akan dibahas, yaitu bagaiman amenyusun sebuah putusan hukum yang berkeadilan dengan melalui hermeneutika.

\section{PEMBAHASAN}

Indonesia sebagai negara hukum sebagaimana disebutkan dalam penjelasan Undang Undang Dasar 1945 maka seluruh kegiatan kenegaraan harus didasarkan atas hukum. Istilah negara hukum merupakan terjemahan dari rechtstaat (bahasa Belanda), yang menurut Soetandyo Wignyosoebroto terjemahan tersebut hanya merupakan terjemahan secara harafiah saja dan tidak bisa dikatakan merupakan penerjemahan yang lebih bersifat konseptual dan/atau sintagmatis. ${ }^{4}$ Lebih lanjut dikatakan bahwa istilah rectstaat di dalam bahasa Belanda (atau lawstate di dalam bahasa Inggris) itu dapatlah pula diartikan sebagai "status hukum". Maksudnya ialah status yang tertinggi dalam hirarki norma-norma ketertiban di

\footnotetext{
${ }^{4}$ Soetandyo Wignyosoebroto, 2002, Hukum Paradigma, Metode dan Dinamika Masalahnya, Elsam dan Huma, Jakarta, hal. 472.
} 
dalam kehidupan bernegara dan bermasyarakat, atau yang di dalam bahasa Inggris dikatakan the supreme state of law. Dengan kata lain hukum itulah yang harus dirujuk pertama-tama, dengan mengatasi atau mengungguli norma-norma apa pun lainnya, demi terwujudnya kehidupan bersama di dalam organisasi negara. Selanjutnya apabila dikatakan bahwa hukum akan menjadi rujukan pertamatama, lalu muncul pertanyaan, apa yang dimaksud dengan hukum di sini atau hukum yang mana?

Menurut kaum positivis, yang dimaksud dengan hukum adalah normanorma keadilan (ius) yang telah dibentuk (constitutum, constitude) menjadi aturanaturan hidup oleh suatu badan legislatif melalui berbagai prosedur yang formal, dan yang kemudian diumumkan (diundangkan) sebagai hukum yang berlaku secara pasti (di-“iya"-kan, dipositifkan) dalam suatu wilayah negara tertentu, yang oleh karena itu pula akan mengikat seluruh warga negara tanpa kecualinya. Hal tersebut disebut juga hukum Undang-undang (lege, lex, ius constitutum) sehingga prosedurnya disebut hukum formal, yang kemudian sering juga disebut hukum negara, diundangkan sebagai produk badan legislatif.

Teori Hart tentang hukum positif menyatakan bahwa esensi hukum terletak pada penggunaan unsur paksaan. ${ }^{5}$ Kemudian Lon L. Fuller ${ }^{6}$ menekankan pada isi hukum positif, karena harus memenuhi delapan persyaratan formal, yaitu :

1) Hukum yang bersifat umum memerlukan peraturan-peraturan, artinya syarat ini menyentuh hakekat dari tata hukum. Agar suatu tata hukum dapat ditegakkan maka seyogyanya diusahakan mempengaruhi tingkah laku dan (kemungkinan) penyelesaian perselisihan.

2) Aturan seharusnya diumumkan agar aturan tersebut dapat memenuhi fungsi mengaturnya. Baik untuk mengemudikan tingkah laku maupun untuk menyelesaikan perselisihan perlu bahwa orang mengenal aturan yang bersangkutan.

3) Aturan tidak boleh berlaku surut. Apabila aturan hukum itu dilihat sebagai alat untuk mengemudikan tingkah laku (yang akan datang), maka mudah dipahami bahwa undangundang tidak boleh berlaku surut.

4) Aturan harus jelas, tidak boleh diartikan ganda. Aturan harus menjaga membantu penyelesaiannya sehingga tidak boleh mengundang persoalan.

5) Aturan tidak boleh bertentangan secara batin. Pembuat aturan tidak boleh memerintahkan sesuatu dan pada saat yang sama melarang sesuatu yang sama itu.

5 Kudzaifah Dimyati, 2004, Teorisasi Hukum, Studi Tentang Perkembangan Pemikiran Hukum Di Indonesia 1945 - 1990, Muhammadiyah University Press, Surakarta, hal. 62.

${ }^{6}$ N.E. Algra, et.al, 1983, Mula Hukum, Bina Cipta, Jakarta, hal. $122-128$. 
6) Aturan tidak boleh menuntut hal yang tidak mungkin.

7) Aturan seyogyanya mempunyai sesuatu keadaan tertentu yang tidak berubah (zekere consistentie).

8) Aturan tidak boleh hanya untuk para justisiabel, tetapi berlaku juga untuk para penguasa.

Teori/aliran positivisme ini selanjutnya menurut Satjipto Rahardjo dikembangkan secara seksama oleh Teori Hukum Murni dari Hans Kelsen. Teori Hukum Murni menolak ajaran yang bersifat ideologis dan hanya menerima hukum sebagaimana adanya, yaitu dalam bentuk peraturan-peraturan yang ada. Menurut Kelsen, teori Hukum Murni adalah teori tentang hukum positif.

Teori Hans Kelsen yang terkenal dengan "Reine Rechtslehre" nya (Ajaran Murni Tentang Hukum) menjelaskan bahwa ajaran tentang hukum harus secara tajam dipisahkan di satu pihak dari ilmu sosiologis, di lain pihak dari tiap postulat etikal yang menyebabkan orang jatuh kembali ke dalam suatu hukum kodrat yang justru mau dihindarkan. ${ }^{8}$

Aliran berikutnya adalah aliran Kaum Realis yang berpendapat bahwa arti hukum (rechts) di samping termasuk

\footnotetext{
${ }^{7}$ Satjipto Rahardjo, 1996, op cit, hal. 272

8 B. Arief Sidharta, 2003, Struktur Ilmu Hukum ( terjemahan dari De Structuur der Rechtswetenschap, Paul Scholten, ceramah pada pertemuan Koninklijke Nederlansche Akademie van Wetenschappen, Afdeeling Letterkunde, 17 Maret 1942 ), PT Alumni, Bandung, hal. 5
}

hukum perundang-undangan yang tertulis juga tata normatif yang berlaku secara partikular sebagai tradisi atau "hukum tak tertulis".

Melanjutkan kaum realis adalah munculnya kaum/aliran kritik, yang mengatakan bahwa hukum tidak hanya terbatas pada undang-undang tetapi terbuka untuk interpretasi yang berbedabeda. $^{9}$

Selanjutnya setelah kita mengetahui tentang pengertian atau ruang lingkup dari hukum, maka sebagai pedoman tingkah laku hukum mempunyai fungsi-fungsi sebagai berikut: ${ }^{10}$

1) Sebagai sarana pengendalian sosial (social control);

2) Sebagai sarana untuk melakukan social engineering;

3) Melakukan fungsi integrasi.

Sebagai sarana pengendalian sosial, hukum diharapkan dapat digunakan menganjurkan, menyuruh atau bahkan memaksa anggota-anggota masyarakat agar mematuhi norma-norma hukum atau tata tertib hukum yang sedang berlaku. ${ }^{11}$ hal. 475

9 Soetandyo Wignyosoebroto, 200, opcit,

10 Talcott Parsons dalam buku Ronny Hanitijo Soemitro, 1984, Permasalahan Hukum Di Dalam Masyarakat, Alumni, Bandung, hal. 3

11 Soerjono Soekanto, 1975, Beberapa Permasalahan dalam Kerangka Pembangunan Di Indonesia, Yayasan Penerbit Universitas Indonesia, hal. 75 . 
Sebagai sarana untuk melakukan social engineering, maka hukum diharapkan dapat merubah perilaku anggota masyarakat sebagaimana yang diatur dalam hukum tersebut.

Selanjutnya fungsi hukum yang ketiga adalah fungsi integrasi. Menurut Talcott Parsons, fungsi utama dari suatu sistem hukum adalah melakukan fungsi integrasi, yaitu mengurangi konflik-konflik dan melancarkan proses interaksi pergaulan sosial $^{12}$.

Lebih lanjut dikatakan bahwa lembaga pengadilan merupakan suatu mekanisme yang berfungsi untuk menciptakan integrasi yang menghasilkan koordinasi di dalam masyarakat. Dengan lembaga pengadilan, maka kepentingankepentingan anggota masyarakat diintegrasikan, sehingga kepentingan yang dilanggar dapat dipulihkan kembali. Dalam mengintegrasikan kepentingan yang bertentangan di antara anggota masyarakat dalam bentuk keputusan pengadilan tidaklah mudah untuk dilakukan, karena putusan tersebut harus mewujudkan kepastian hukum, kemanfaatan dan keadilan.

Dalam menjalankan integrasi tersebut hukum tidak sepenuhnya otonom, oleh karena ia hanya dapat menjalankan fungsinya tersebut dengan dan apabila

\footnotetext{
${ }^{12}$ Ronny Hanitijo Soemitro, Op cit, hal. 10
}

menerima pengarahan dari sub sistem budaya yang memberikan masukan tentang nilai-nilai mana yang dijunjung oleh hukum dalam menjalankan fungsi integrasinya. $^{13}$ Dengan fungsi integrasi sebagaimana dikemukakan oleh Talcott Parsons yang diwujudkan melului lembaga pengadilan maka hakim sebagai aparat lembaga pengadilan diharapkan dapat melaksanakan tugasnya.

Tugas pokok hakim pengadilan adalah menerima, memeriksa dan mengadili serta menyelesaikan setiap perkara yang diajukan kepadanya. Hakim tidak boleh menolak untuk memeriksa dan mengadili perkara yang diajukan dengan dalih bahwa hukumnya tidak ada atau kurang jelas, melainkan wajib untuk memeriksa dan mengadilinya.

Fungsi atau tugas tersebut tidak hanya menyelesaikan konflik/sengketa saja, tetapi pengadilan juga mengadili perkara yang tidak timbul dari suatu sengketa. Oleh karena itu, produk hukum yang dihasilkan oleh pengadilan dapat berupa putusan (vonnis) dan penetapan (beschikking). Suatu produk pengadilan yang berupa putusan diambil untuk menyelesaikan atau mengakhiri suatu sengketa, sedangkan suatu produk

13 Satjipto Rahardjo, 1996, Transformasi Nilai-nilai Dalam Penemuan dan Pembentukan Hukum Nasional, dalam Majalah Hukum Nasional, BPHN DEPKEH\&HAM, Jakarta, hal. 4 
pengadilan yang berupa penetapan diambil berhubung atas dasar suatu permohonan.

Fungsi atau tugas hakim tersebut harus dilaksanakan dengan mengindahkan asas yang berlaku dalam sistem peradilan yaitu tercapainya peradilan yang sederhana, cepat dan biaya ringan. Berlarut-larutnya atau tertundanya jalannya peradilan yang mengakibatkan berkurangnya kewibawaan pengadilan (justice delayed is justice denied) $^{14}$.

Hal tersebut juga didasari atas pemikiran bahwa ketika para pihak yang bersengketa mengambil langkah untuk menyelesaikan sengketa di antara mereka dengan meminta bantuan pengadilan, maka hal ini berarti bahwa di antara mereka sudah tidak mampu lagi untuk menyelesaikan sengketa sendiri atau menyelesaikana sengketa secara langsung (face to face). ${ }^{15}$

Bagi mereka, kemungkinan untuk menyelesaikan sengketa melalui jalan musyawarah sudah semakin jauh dan semakin mendekati jalan buntu. Para pihak yang bersengketa akan tetap berpegang pada pendiriannya masing-masing dan mereka tidak mungkin lagi menemukan kesepakatan bersama dalam menyelesaikan

${ }^{14}$ Sudikno Mertokusumo, op cit, hal. 82

15 Binoto Nadapdap, 2003, Mendambakan Putusan Hakim Yang Berwibawa, Jurnal Keadilan Vol. 3. No. 2, hal. 13. perse-lisihan/sengketa yang mereka hadapi.

Oleh karena itu, untuk menyelesaikan sengketa tersebut negara menyediakan lembaga yang bertugas untuk itu yaitu adanya lembaga peradilan, yang terdiri dari Pengadilan Negeri sebagai pengadilan tingkat pertama, Pengadilan Tinggi sebagai pengadilan tingkat banding dan Mahkamah Agung sebagai puncak peradilan di negeri ini.

Putusan hakim adalah pernyataan hakim sebagai Pejabat Negara (pada Mahkamah Agung) atau sebagai Pejabat Kekuasaan Kehakiman (pada Pengadilan Negeri dan Pengadilan Tinggi) yang melaksanakan tugas kekuasaan kehakiman, yang diberi wewenang untuk menyelesaikan sengketa/perselisihan. Dengan kata lain putusan hakim adalah suatu pernyataan yang oleh hakim sebagai pejabat negara yang diberi wewenang untuk itu dan bertujuan untuk mengakhiri atau menyelesaikan suatu perkara/sengketa. Oleh karena itu, hakim yang mengambil putusan tersebut bertindak atas nama negara yang harus melindungi setiap warga negara di negeri tercinta ini melalui putusan yang berkeadilan dan berwibawa. Putusan tersebut juga tidak bnerakhir sampai pada menjatuhkan putusan, tetapi juga 
menyelesaikannya sampai pada pelaksanaannya.

Pada uraian terdahulu telah dikemukakan bahwa tugas pokok hakim adalah memberikan putusan yang mencerminkan keadilan. Para pihak yang bersengketa, baik perkara pidana (antara pelaku kejahatan dan masyarakat yang diwakili negara) maupun perkara yang bersifat keperdataan (antara penggugat dan tergugat) selalu menghendaki adanya putusan yang adil. Demikian pula hakim yang akan menjatuhkan putusan juga akan berbuat adil sebagaimana "irah-irah" dalam putusannya, yaitu: "DEMI KEADILAN BERDASARKAN KETUHANAN YANG MAHA ESA". Misalnya, dalam perkara perdata, pihak penggugat dalam gugatannya di samping mengajukan tuntutan pokok (petitum primair) juga disertai dengan tuntutan pengganti (petitum subsidiair). Isi dari tuntutan pengganti (petitum subsidiair) itu biasanya berbunyi " agar hakim mengadili menurut keadilan yang benar" atau "mohon putusan yang seadil-adilnya".

Dari tuntutan subsidiair tersebut dapat disimpulkan bahwa putusan keadilan merupakan tujuan yang sangat didambakan oleh penggugat maupun pihak tergugat.

Pergaulan antar anggota masyarakat selalu dinamis, sehingga kepentingan mereka selalu mengikuti pula perkembangan dunia yang sangat dinamis ini. Oleh karena itu, kepentingan anggota masyarakat yang selalu berkembang dan tuntutan materialisme yang semakin kuat, maka kepentingan anggota masyarakat yang satu dengan yang lain tak jarang terjadi perselisihan yang berkembang menjadi sengketa. Sengketa tersebut untuk kasus-kasus tertentu kadang dapat diselesaikan di luar pengadilan sepereti melalui mediasi, konsiliasi, arbitrase dan lain-lain. Akan tetapi, sengketa tersebut kadang juga diajukan ke lembaga pengadilan.

Dalam menghadapi sengketa yang selalu dinamis tersebut kadang dijumpai atau dapat ditemukan hukum/ peraturan yang mengaturnya, tetapi juga tak jarang antara sengketa atau kasus tersebut tidak ada hukumnya atau hukumnya tidak jelas.

Sejak munculnya kodifikasi dalam wujud undang-undang, sudah diketahui dan dipahami bahwa undang-undang itu tidak dapat memuat hukum secara lengkap ${ }^{16}$, padahal hakim tidak dapat dan tidak boleh menangguhkan atau menolak memeriksa atau menjatuhkan putusan dengan alasan karena hukumnya tidak lengkap atau tidak jelas, dan mau tidak

16 Sudikno Mertokusumo, 1991, Pengantar Penemuan Hukum ( terjemahan dari Law Making Process dari van der Burght ), Bahan Penataran penemuan Hukum I \& II, Yogyakarta, hal. 4 
mau ia harus menjatuhkan putusan. Oleh karena itu, dalam menghadapi kasus yang tidak ada hukumnya (yang tertulis) maka hakim harus berusaha menemukan hukumnya. Usaha menemukan hukum itulah yang selanjutnya dikenal dengan penemuan hukum (rechtsvinding).

\section{Menurut Paul Scholten 17,}

hukum adalah suatu keseluruhan aturanaturan dan kewenangan yang tersusun secara logikal (suatu bangunan logikal) pada suatu masyarakat tertentu dalam suatu waktu tertentu. Aturan-aturan yang berbentuk hukum ini terus menerus berubah dan tidak pernah tertutup. Hukumnya yang in konkreto adalah tidak jelas. Hal ini setiap kali harus ditemukan. Penemuan hukum lazimnya diartikan sebagai proses pembentukan hukum oleh hakim atau petugas-petugas hukum lainnya yang diberi tugas melaksanakan hukum terhadap peristiwa-peristiwa hukum yang konkret. Usaha menemukan hukum yang dilakukan oleh hakim di lingkungan pengadilan itulah yang sering disebut dengan interpretasi.

Berusaha untuk mencapai pemahaman atas sesuatu hukum/peraturan yang tidak jelas diperlukan filsafat tentang

17 B. Arief Sidharta, 2003, Struktur Ilmu Hukum ( terjemahan dari De Structuur der Rechtswetenschap, Paul Scholten, ceramah pada pertemuan Koninklijke Nederlansche Akademie van Wetenschappen, Afdeeling Letterkunde, 17 Maret 1942 ), Alumni, Bandung, hal. 63. hal mengerti atau memahami sesuatu yang sering disebut dengan hermeneutik. Hermeneutik adalah ilmu tentang menafsirkan. ${ }^{18} \quad$ Dengan melalui hermeneutik maka akan dapat dicapai pemahaman dan pengertian yang hakiki atas esensi dari hukum yang tidak jelas atau tidak lengkap tersebut.

Ketentuan Undang-undang tidak dapat diterapkan begitu saja secara langsung pada peristiwanya. Untuk dapat menerapkan ketentuan Undang-undang yang berlaku umum dan abstrak sifatnya itu pada peristiwanya yang konkrit dan khusus sifatnya, ketentuan-ketentuan Undang-undang itu harus diberi arti, dijelaskan atau ditafsirkan adan diarahkan atau disesuaikan dengan peristiwanya. Peristiwa hukumnya harus dicari lebih dahulu dari peristiwa konkritnya, kemudian Undang-undang ditafsirkan untuk dapat diterapkan.

Interpretasi atau penafsiran merupakan salah satu metode penemuan hukum yang memberi penjelasan yang gamblang mengenai teks Undang-undang agar ruang lingkup kaedah dapat ditetapkan sehubungan dengan peristiwa tertentu. Penafsiran oleh hakim merupakan penjelasan yang harus menuju kepada

18 B. Arief Sidharta, 2005, Filsafat IlmuIlmu ( terjemahan dari Filosofie van de Wetwnschappen, C.A. van Peursen, Martinus Nijhoff, Leiden, 1986 ), hal. 15. 
pelaksanaan yang dapat diterima oleh masyarakat mengenai peraturan hukum terhadap peristiwa yang konkrit.

Metode interpretasi ini adalah sarana atau alat untuk mengetahui makna Undang-undang. Pembenarannya terletak pada kegunaannya untuk melaksanakan ketentuan yang konkrit dan bukan untuk kepentingan metode itu sendiri. Interpretasi ini biasanya sering dimanfaatkan di negara-negara Civil Law System, yang sebagian besar peraturan-peraturannya bersifat tertulis, meskipun di negara-negara yang Common Law System sudah dijumpai banyak peraturan tertulis. ${ }^{19}$

Metode interpretasi yang ada bukanlah merupakan metode yang diperintahkan kepada hakim untuk digunakan dalam penemuan hukum, tetapi merupakan penjabaran-penjabaran putusan hakim. Dari alasan-alasan atau pertimbangan-pertimbangan yang sering digunakan oleh hakim dalam menemukan hukumnya dapat disimpulkan adanya metode interpretasi sebagai berikut $:^{20}$

19 Satjipto Rahardjo, 2005, Penafsiran Hukum Yang Progresif ( Bahan Bacaan Mahasiswa S3 ), PDIH UNDIP, Semarang, hal. 2.

20 Sudikno Mertokusumo, 1993, Bab-bab Tentang Penemuan Hukum, Citra Aditya Bakti, Bandung, hal. 14. Lebih lanjut dijelaskan mengenai pengertian dari metode-metode penafsiran itu. 1) Penafsiran menurut bahasa merupakan cara penafsiran atau penjelasan yang paling sederhanauntuk mengetahui makna ketentuan Undang-undang dengan menguraikannya menurut bahasa, susun kata atau bunyinya.
1) Penafsiran/interpretasi menurut bahasa (gramatikal);

2) Penafsiran/interpretasi teleologis atau sosiologis;

3) Penafsiran/interpretasi sistematis atau logis;

4) Penafsiran/interpretasi historis;

5) Penafsiran/interpretasi perbandingan hukum (komparatif);

6) Penafsiran/interpretasi futuristis. Biasanya yang memerlukan penafsiran itu adalah perjanjian dan Undang-undang, karena baik Undangundang atau pun perjanjian seringkali tidak jelas atau tidak lengkap. Dengan menggunakan interpretasi, khususnya dengan memperhatikan hermeneutik, maka undang-undang atau perjanjian yang ditafsirkan akan menjadi jelas, sehingga putusan yang dijatuhkan oleh hakim atas suatu kasus konkrit yang hukumnya tidak jelas atau tidak lengkap tersebut dapat lebih mencerminkan keadilan.

Dengan putusan hakim yang mencerminkan dan mewujudkan keadilan dan tidak memihak pada salah satu pihak yang berperkara, maka putusan tersebut

2) Interpretasi teleologis atau sosiologis yaitu apabila makna Undang-undang itu ditetapkanb berdasarkan tujuan kemasyarakatan. 3) Interpretasi sistematis yaitu menafsirkan Undangundang sebagai bagian dari keseluruhan system perundang-undangan dengan jalan menghubungkannya dengan Undang-undang lain.

4) Interpretasi historis yaitu menafsirkan atau menjelaskan makna Undang-undang dengan jalan meneliti sejarah terjadinya. 5) Penafsiran komparatif yaitu penafsiran dengan cara memperbandingkan dengan ketentuan Undangundang lain. 6) Penafsiran futuristis adalah penjelasan ketentuan Undang-undang dengan berpedoman pada Undang-undang yang belum mempunyai kekuatan hukum. 
akan menjadi berwibawa, sehingga para pihak akan legawa untuk melaksanakan putusan hakim tersebut. Putusan hakim juga akan berwibawa dan diterima para pihak jika alasan-alasan hukum yang dijadikan dasar dalam mengambil putusan itu bermutu, memadai.

Sebagaimana halnya dinyatakan John Chipman Gray bahwa fungsi hakim dalam mengadili suatu perkara/sengketa adalah: their function ( judge) is not mainly to declare the law, but to maintain the peace by deciding controversies, which is to say, by determining the legal rights and duties of the parties. When a controversy comes before a judge, he must decide the case, he lays down a rule that settles the rights and duties of the parties; that rule is the law and yet the rights and duties of the parties were not known by them. That is the way the parties are treated and have to be treated by the courts". ${ }^{21}$

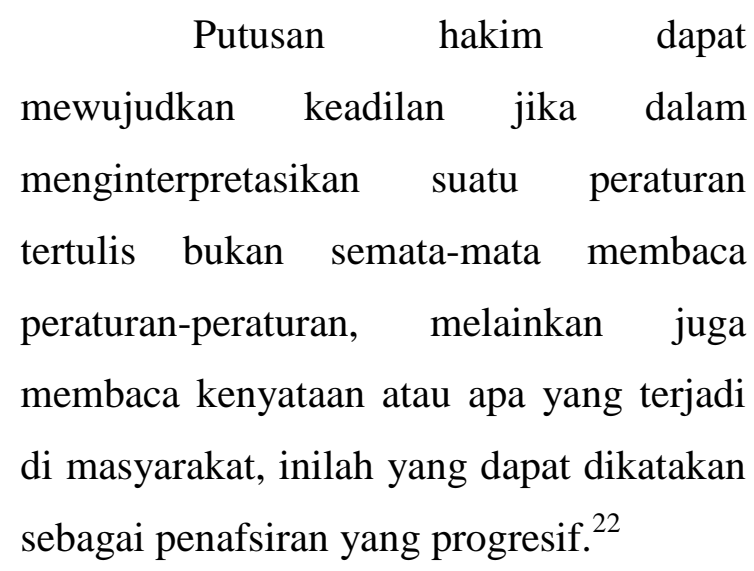

${ }^{21}$ Theodore M. Benditt, 1978, Law as Rule and Principle : Problem of Legal Philosophy, Stanford University Press, California, hal. 8.

${ }^{22}$ Satjipto Rahardjo, 2005, op cit, hal 8.

\section{PENUTUP}

Dari permasalahan dan uraian pembahasan di atas maka dapat disimpulkan bahwa hakim pengadilan akan dapat memberikan/menjatuhkan putusan yang berkeadilan terhadap kasus/perkara yang dihadapinya, dan yang tidak ada hukumnya jika hakim tersebut dapat menemukan hukum melalui hermeneutika atau interpretasi terhadap peraturan tertulis tersebut dengan menggunakan metode yang tepat. Putusan hakim tersebut akan berwibawa artinya dipatuhi pelaksanaannya oleh para pihak jika hakim dapat bertindak adil yaitu tidak memihak pada salah satu pihak yang berperkara. Bagaimanapun putusan hakim selalu mempunyai akibat hukum bagi para pihak dan juga pihak yang lain. Jika hakim hendak menjatuhkan putusan, maka ia akan selalu berusaha agar putusannya sejauh mungkin dapat diterima oleh masyarakat luas, sehingga putusannya menjadi berwibawa.

Saran yang bisa disampaikan agar putusan hakim mencerminkan keadilan dan berwibawa adalah agar alasan-alasan hukum yang dijadikan dasar dalam mengambil putusan itu bermutu dan memadai sebagaimana yang diharapkan oleh Undang-undang dan rasa keadilan yang disuarakan oleh masyarakat luas. 


\section{DAFTAR PUSTAKA}

B. Arief Sidharta, 2003, Struktur Ilmu Hukum (terjemahan dari De Structuur der Rechtswetenschap, Paul Scholten, ceramah pada pertemuan Koninklijke Nederlansche Akademie van Wetenschappen, Afdeeling Letterkunde, 17 Maret 1942 ), PT Alumni, Bandung. , 2005, Filsafat Ilmu-Ilmu (terjemahan dari Filosofie van de Wetwnschappen, C.A. van Peursen, Martinus Nijhoff, Leiden, 1986).

Binoto Nadapdap, 2003, Mendambakan Putusan Hakim Yang Berwibawa, Jurnal Keadilan Vol. 3. No. 2.

Kudzaifah Dimyati, 2004, Teorisasi Hukum, Studi Tentang Perkembangan Pemikiran Hukum Di Indonesia $1945 \quad-\quad$ 1990, Muhammadiyah University Press, Surakarta.

N.E. Algra, et.al, 1983, Mula Hukum, Bina Cipta, Jakarta.

Ronny Hanitijo Soemitro, 1984, Permasalahan Hukum Di Dalam Masyarakat, Alumni, Bandung.

Satjipto rahardjo, 1996, Ilmu Hukum, Citra Aditya Bakti, Bandung.

Satjipto Rahardjo, 1996, Transformasi Nilai-nilai Dalam Penemuan dan Pembentukan Hukum Nasional, dalam Majalah Hukum Nasional, BPHN DEPKEH\&HAM, Jakarta.

Satjipto Rahardjo, 2005, Penafsiran Hukum Yang Progresif (Bahan Bacaan Mahasiswa S3 ), PDIH UNDIP.

Soerjono Soekanto, 1975, Beberapa Permasalahan dalam Kerangka

\section{Pembangunan Di Indonesia, Yayasan Penerbit Universitas Indonesia.}

Soetandyo Wignyosoebroto, 2002, Hukum Paradigma, Metode dan Dinamika Masalahnya, Elsam dan Huma, Jakarta.

Sudikno Mertokusumo, 1982, Hukum Acara Perdata Indonesia, Liberty, Yogyakarta. 1988, Mengenal Hukum ( Suatu Pengantar ) , Liberty, Yogyakarta.

1991, Pengantar Penemuan Hukum ( terjemahan dari Law Making Process dari van de Burght ), Bahan Penataran penemuan Hukum I \& II, Yogyakarta. , 1993, Bab-bab Tentang Penemuan Hukum, Citra Aditya Bakti, Bandung.

Theodore M. Benditt, 1978, Law as Rule and Principle : Problem of Legal Philosophy, Stanford University Press, California. 